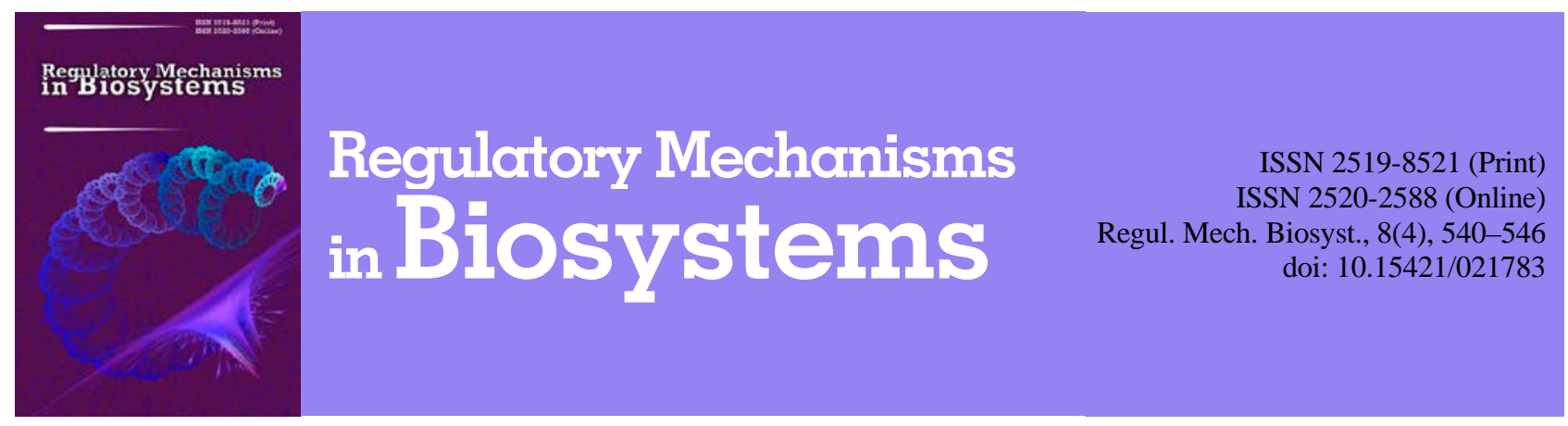

\title{
Resistance of nosocomial strains to antibacterial drugs and its link to biofilm formation
}

\author{
T. V. Sklyar, K. V. Lavrentieva, Y. A. Alyonkina, A. M. Kolomoets, A. I. Vinnikov \\ Oles Honchar Dnipro National University, Dnipro, Ukraine
}

\section{Article info}

Received 18.10.2017

Received in revised form 11.11.2017

Accepted 16.11.2017

Oles Honchar Dnipro National University, Gagarin Ave., 72, Dnipro, 49010, Ukraine. Tel.: +38-050-158-62-78 Email: microviro@ukr.net

\begin{abstract}
Sklyar, T. V., Lavrentieva, K. V., Alyonkina, Y. A., Kolomoets, A. M., \& Vinnikov, A. I. (2017). Resistance of nosocomial strains to antibacterial drugs and its link to biofilm formation. Regulatory Mechanisms in Biosystems, 8(4), 540-546. doi:10.15421/021783

The problem of nosocomial infections is considered in connection with more frequent formation and wide distribution in clinical practice of new strains of hospital bacteria that have a cross-resistence to antibacterial drugs. The nosocomial agents were isolated from wounds and identified as Staphylococcus aureus and Pseudomonas aeruginosa. $72.0 \%$ of $S$. aureus strains and $61.5 \%$ of $P$. aeruginosa clinical isolates had the capability of forming biofilms. The sensitivity to antibiotics of all isolated strains was investigated with tne agar diffusion test. This method showed that all strains of $S$. aureus with the capability to form biofilms had resistence to erythromycin, gentamycin, ciprofloxacin and levofloxacin. The had the greatest sensitivity to klindamycin (90.3\%), vancomycin (80.6\%) and gatifloxacin $(80.6 \%$ cultures). The strains of $S$. aureus with the capability to form biofilms were more resistent to antibiotics than strains of $S$. aureus without such properties. Only cefotaxim suppressed the growth of $75.0 \%$ of strains of staphylococci. All isolated strains of $S$. aureus without the capability to form biofilms were sensitive to doxycyclin, gentamycin, ciprofloxacin, levofloxacin and klindamycin. All clinical isolates of $P$. aeruginosa with capability to form biofilms had resistence to ampicillin, gentamycin, imipenem, cefotaxime and ceftriaxone. They were most sensitive (75.0\%) to piperacillin and cefoperazone/sulbactam. The strains of $P$. aeruginosa without the capability to form biofilms kept the resistence to gentamycin, imipenem and ceftriaxone. They showed the greatest sensitivity (75.0\%) to ciprofloxacin (80.0\% isolates) and also to amikacin, ampicillin, meropenem, norfloxacin and cefotaxime (60.0\% cultures). We investigated the minimum inhibitory concentrations of gentamycin and ciprofloxacin, which appeared higher for $P$. aeruginosa than for $S$. aureus. The most effective disinfectant against all isolated nosocomial agents without the capacity for biofilm formation was "Desactin" in a concentration $0.1 \%$ or $0.2 \%$. For strains of staphylococci with this capability, the efficiency of "Desactin" went down by $9.7 \%$. The best biocide effect against the strains of P. aeruginosa with the capability of forming biofilms was shown by $0.1 \%$ solution of "Neochlorine tabs", which suppressed the growth of $75.0 \%$ of tested cultures. As a result, we detected a direct relationship between resistance to antibiotics and disinfectants and the capacities for biofilm formation among the nosocomial agents $S$. aureus and P. aeruginosa.
\end{abstract}

Keywords: antibiotics; disinfectants; biofilm; Pseudomonas aeruginosa; Staphylococcus aureus

\section{Резистентність збудників внутрішньолікарняних інфекцій до антибактеріальних препаратів та ї̈ зв'язок із плівкоутворенням}

\author{
Т. В. Скляр, К. В. Лаврентьєва, Ю. А. Альонкіна, А. М. Коломоєць, А. І. Вінніков \\ Дніпровський наиіональний університет імені Олеся Гончара, Дніпро, Україна
}

Розглянуто проблему внутрішньолікарняних інфекцій у зв'язку зі все частішим формуванням і широким розповсюдженням у клінічній практиці нових госпітальних штамів мікроорганізмів, що мають перехресну стійкість до антибактеріальних препаратів. Із відокремлюваного ран виділено збудників внутрішньолікарняних інфекцій, ідентифікованих як Staphylococcus aureus i Pseudomonas aeruginosa. Здатність до плівкоутворення мали 72,0\% виділених штамів золотистого стафілокока та 61,5\% клінічних ізолятів синьогнійної палички. Під час визначення антибіотикочутливості штамів диско-дифузійним методом найбільша кількість збудників внутрішньолікарняних інфекцій, здатних до плівкоутворення, проявила резистентність до гентаміцину, ципрофлоксацину та цефотаксиму. Методом мінімальних серійних розведень визначено, що вищий рівень резистентності за значеннями МПК ципрофлоксацину та гентаміцину мали клінічні штами синьогнійної палички порівняно з золотистим стафілококом. Найефективніший дезінфектант проти клінічних неплівкотвірних штамів золотистого стафілокока та синьогнійної палички - «Дезактин» у концентрації $0,1-0,2 \%$. Відносно ізолятів $S$. aureus, здатних до плівкоутворення, його ефективність знизилась на 9,7\%. Найкращий бактерицидний ефект відносно плівкотвірних штамів $P$. aeruginosa мав $0,1 \%$ розчин «Неохлор табс», який пригнічував ріст 75,0\% тестованих культур. У клінічних штамів $S$. aureus та $P$. aeruginosa - збудників 
внутрішньолікарняних інфекцій - існує прямий взаємозв’язок між показниками їх стійкості до антибіотиків і дезінфектантів і здатністю культур до плівкоутворення.

Ключові слова: антибіотики; дезінфектанти; біопівки; Pseudomonas aeruginosa; Staphylococcus aureus

Вступ

У сучасних умовах невід’ємна частина діяльності державних медичних установ - контроль за циркуляцією в лікувально-профілактичних установах полірезистентних до антибіотиків і дезінфектантів штамів бактерій - збудників внутрішньолікарняних інфекцій, здійснення заходів щодо обмеження їх подальшого розповсюдження та попередження формування нових госпітальних варіантів.

Нині внутрішньолікарняні інфекції - всесвітня медична, соціальна та економічна проблема (Menegueti et al., 2015; Sonmezer et al., 2016; Rezai et al., 2017). Рівень поширення внутрішньолікарняних інфекцій у країнах Свропи та США в середньому становить 8,0-9,0\% усіх госпіталізованих хворих. У США він складає 4,5\%, у Франції - 6,7\%, Італії - 8,3\%, Швейцарії - 10,1\%, Канаді - 11,6\%, Кореї - 5,7\%, Австралії - 16,6\%, Греції - 9,3\%. За даними ВОЗ, щорічно від ускладнень внутрішньолікарняних інфекцій помирає 50-90 тис. пацієнтів у США і 5 тис. осіб у Великій Британії. В Україні протягом останніх 10 років рівень захворюваності на внутрішньолікарняні інфекції постійно зростає, а летальність становить 3,5-60,0\% залежно від нозологічної форми (Taran, 2014). Водночас із соціальним виникає також юридичне питання, коли пацієнт або його сім'я звинувачують працівників лікарні в інфікуванні та вимагають матеріального відшкодування (Dasgupta et al., 2015).

Основні причини появи та розвитку внутрішньолікарняних інфекцій - формування та селекція в умовах стаціонару госпітальних штамів мікроорганізмів із високою вірулентністю та множинною стійкістю до лікарських засобів; нераціональна антимікробна хіміотерапія; недостатній контроль за циркуляцією умовно-патогенних і патогенних культур; високий рівень носійства збудників внутрішньолікарняних інфекцій серед медичних працівників; недотримання правил асептики та антисептики; порушення санітарно-епідемічного режиму в лікувально-профілактичних установах тощо (Scherbaum et al., 2014).

Спектр збудників внутрішньолікарняних інфекцій значний. Вони можуть бути викликані найпростішими (Pneumocystis carinii), грибами (Candida sp.), вірусами (віруси гепатитів В і C, ВІЛ, ентеровіруси тощо). Але перше місце в етіологічній структурі внутрішньолікарняних інфекцій посідають бактеріальні агенти: ентерококи, Streptococcus spp., Staphylococcus spp., Acinetobacter spp., Bacillus cereus, Legionella spp., представники родини Enterobacteriaceae (Proteus mirablis, Klebsiella pneumoniae, Escherichia coli, Serratia marcescens). Найголовніша роль у виникненні внутрішньолікарняних інфекцій, за даними всесвітньої статистики, належить Pseudomonas aeruginosa та Staphylococcus aureus (Abdallah et al., 2014; Khan et al., 2015; Murphy et al., 2016).

За результатами досліджень, проведених у західноєвропейських ICUs, частота висіву P. aeruginosa становить 17,0\% від загальної кількості виділених госпітальних штамів мікроорганізмів і 29,0\% від кількості грамнегативних збудників внутрішньолікарніних інфекцій. Синьогнійну паличку включено до списку патогенів ESKAPE Американського товариства інфекційних хвороб, що становлять найбільшу загрозу для здоров’я населення через поєднання іiі все більшого розповсюдження та неефективності сучасних антибактеріальних засобів, через існування таких механізмів резистентності до антибіотиків, як низька проникність мембрани, продукція декількох антиагрегантів, що інактивують ферменти, та формування біоплівок (Nathwani et al., 2014; Kim et al., 2014; Ali et al., 2015).

Другий значимий етіологічний агент внутрішньолікарняних інфекцій - бактерії роду Staphylococcus i, насамперед, S. aureus. Значний набір факторів патогенності та, водночас, широке та часто безконтрольне використання антимікробних засобів у медичній практиці сприяє формуванню нових госпітальних штамів збудника (Khan et al., 2015; Vuong et al., 2016).
Все частіше з'являються та швидко розповсюджуються у стаціонарах генетично змінені варіанти $S$. aureus зі стійкістю до захищених $\beta$-лактамів, із множинною стійкістю до антибіотиків різних фармакологічних груп, із перехресною стійкістю до багатьох антимікробних препаратів, а також метицилінстійкі штами золотистого стафілокока (MRSA) (Ansari et al., 2014; Sowash et al., 2014; Baldan et al., 2014; Tong et al., 2015; Wang and Ruan, 2017). Останнім часом усе частіше з'являються повідомлення про наявність у збудників внутрішньолікарняних інфекцій явища перехресної стійкості до антибактеріальних засобів: множинної резистентності до антибіотиків на тлі адаптації до дезінфектантів (Abdallah et al., 2014).

Відмінна властивість багатьох збудників внутрішньолікарняних інфекцій від інших мікроорганізмів - здатність до формування біоплівок на об’єктах навколишнього середовища, зокрема, на небіологічних матеріалах, що, за їх контакту з організмом пацієнта, підвищують ризик розвитку в нього септичного стану (Abdallah et al., 2014). Якщо збудники внутрішньолікарняних інфекцій зі здатністю до плівкоутворення водночас матимуть ще перехресну стійкість до лікарських засобів, це значно ускладнить їх елімінацію в умовах стаціонару та перешкоджатиме під час проведення антибактеріальної терапії (Chadha, 2014; Singh et al., 2017).

Мета цього дослідження - оцінити стійкість до антибіотиків і дезінфектантів клінічних штамів мікроорганізмів - збудників внутрішньолікарняних інфекцій, виявити можливі взаємозв’язки між цими показниками та здатністю культур до плівкоутворення.

\section{Матеріал і методи досліджень}

Об’єкт дослідження - відокремлюване ран пацієнтів із внутрішньолікарняними інфекціями. Проби відбирали відповідно до методичних рекомендацій щодо дотримання санітарно-епідеміологічного режиму в закладах охорони здоров’я України.

Тверді шматочки тканин (секвестри, шматочки шкіри, м’язів тощо), узятих стерильним пінцетом з області рани пацієнта, засівали у середовище для контролю стерильності та цукровий бульйон, а рідке (напіврідке) відокремлюване, узяте стерильним ватним тампоном, - ще й на чашку з 5,0\% кров'яним агаром методом «тампон - петля». Тампоном проводили «доріжку» по діаметра чашки, а потім петлею матеріал розсівали паралельними штрихами у напрямку від «доріжки» до перифеpiї чашки. Така техніка розсіву клінічного матеріалу дозволяє виділити чисті культури мікроорганізмів навіть із їх асоціації.

Засіяні рідкі та щільні живильні середовища термостатували за $37^{\circ} \mathrm{C}$. Через 18-24 години проводили відсівання окремих колоній на елективні та диференціально-діагностичні середовища для ідентифікації виділених бактеріальних культур.

Оскільки збудники внутрішньолікарняних інфекцій мають виражені адгезивні властивості та здатність до формування біоплівок, на наступному етапі за допомогою модифікованої методики у виділених штамів мікроорганізмів визначали здатність до плівкоутворення. Для цього у кожну лунку 96-лункового стерильного імунологічного планшета вносили по 200 мкл м'ясопептонного бульйону, який засівали 50 мкл суспензії клітин бактеріальних культур із початковою концентрацією 3,2 $10^{4}$ кл./мл (O’Toole et al., 2000).

Надалі визначали чутливість виділених штамів - збудників внутрішньолікарняних інфекцій до низки антибіотичних препаратів різних фармакологічних груп (диско-дифузійним методом і методом мінімальних серійних розведень) і дезінфектантів (методом батистових тест-об'єктів).

Референтний метод визначення чутливості збудників внутрішньолікарняних інфекцій до антибіотиків - метод серійних 
розведень, тоді як диско-дифузійний метод дозволяє лише опосередковано робити висновок про величину мінімальної пригнічувальної концентрації. В останньому випадку результат дослідження - віднесення мікроорганізму до однієї 3 категорій чутливості: $\mathrm{S}$ - чутливий штам, $\mathrm{R}$ - помірно-стійкий або резистентний.

Спектр антибіотичних препаратів включав амікацин, ампіцилін, гентаміцин, іміпенем, меропенем, цефтазидим, норфлоксацин, ципрофлоксацин, левофлоксацин, гатифлоксацин, цефоперазон / сульбактам, цефоперазон, тетрациклін, цефотаксим, цефтриаксон, піперацилін, цефепім, доксициклін, еритроміцин, кліндаміцин, оксацилін, пеніцилін $\mathrm{G}$, ванкоміцин.

Під час постановки методу батистових тест-об'єктів для отримання мікробної суспензії добову культуру кожного з виділених штамів - збудників внутрішньолікарняних інфекцій змивали стерильною водою, доводили до концентрації 2 млрд клітин в 1 мл суміші (за стандартом каламутності) та додавали $10,0 \%$ інактивованої кінської сироватки. Тест-об'єкти готували таким чином: стерильні шматочки батисту розміром $0,5 \times 1,0 \mathrm{~cm}$ розкладали в чашки Петрі, заливали мікробною суспензією на 15-20 хвилин, висушивали в термостаті між стерильними листами фільтрувального паперу протягом 20 хвилин за $37^{\circ} \mathrm{C}$. Підготовані тест-об'єкти поміщали у чашки Петрі з 0,5 мл тестованого дезінфектанту ( $0,1 \%$ розчин «Дезактин», $0,2 \%$ розчин «Дезактин», 0,03\% розчин «Неохлор табс», 0,1\% розчин «Неохлор табс»). Час експозиції тест-об'єктів із дезінфектантом становив 5, 10, 20, 30, 40 і 60 хвилин. Після експозиції тест-об'єкти послідовно через кожні 5 хвилин переносили у ряд пробірок, перша 3 яких містила розчин нейтралізатора $(0,5 \%$ розчин гіпосульфіту натрію для хлорумісних дезінфектантів або дистильована вода для інших засобів), друга - стерильну водопровідну воду, третя - м’ясопептонний бульйон. Пробірки інкубували в термостаті за $37^{\circ} \mathrm{C}$ протягом 48 годин. Водночас ставили два контролі: культури та м'ясопептонного бульйону. Надалі з пробірок проводили висіви на елективні середовища. Посіви термостатували в термостаті за $37^{\circ} \mathrm{C}$ протягом двох діб. Культури вважали чутливими до тестованого дезінфектанту, якщо ріст мікроорганізму на елективному середовищі відмічали після витримування тест-об’єкту з дезінфікувальним розчином менше 20 хвилин, стійкими - від 20 хвилин (Morozova et al., 2008).

\section{Результати}

Проаналізовано 135 клінічних зразків, із яких виділено 103 штами умовно-патогенних мікроорганізмів. 82 культури $(79,6 \%)$ віднесено до категорії збудників внутрішньолікарняних інфекцій (рис. 1). Із них за вивченням фізіолого-біохімічних ознак 43 штами ідентифіковано як Staphylococcus aureus, 39 - як Pseudomonas aeruginosa. 31 iз 43 штамів золотистого стафілокока мав здатність до плівкоутворення. Із 39 штамів синьогнійної палички здатність до плівкоутворення мали 24 ізоляти.

Під час визначення антибіотикочутливості виділених культур золотистого стафілокока диско-дифузійним методом встановлено, що всі штами, здатні до плівкоутворення, стійкі до еритроміцину, гентаміцину, ципрофлоксацину та левофлоксацину (рис. 2).

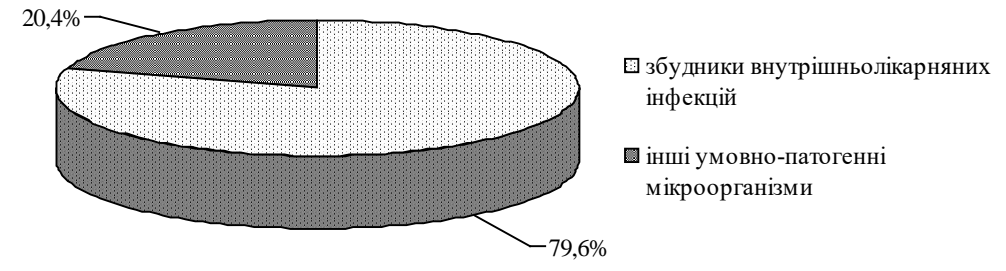

Рис. 1. Частота виділення госпітальних штамів бактерій із дослідних клінічних зразків пацієнтів із ВЛІ (n = 103)

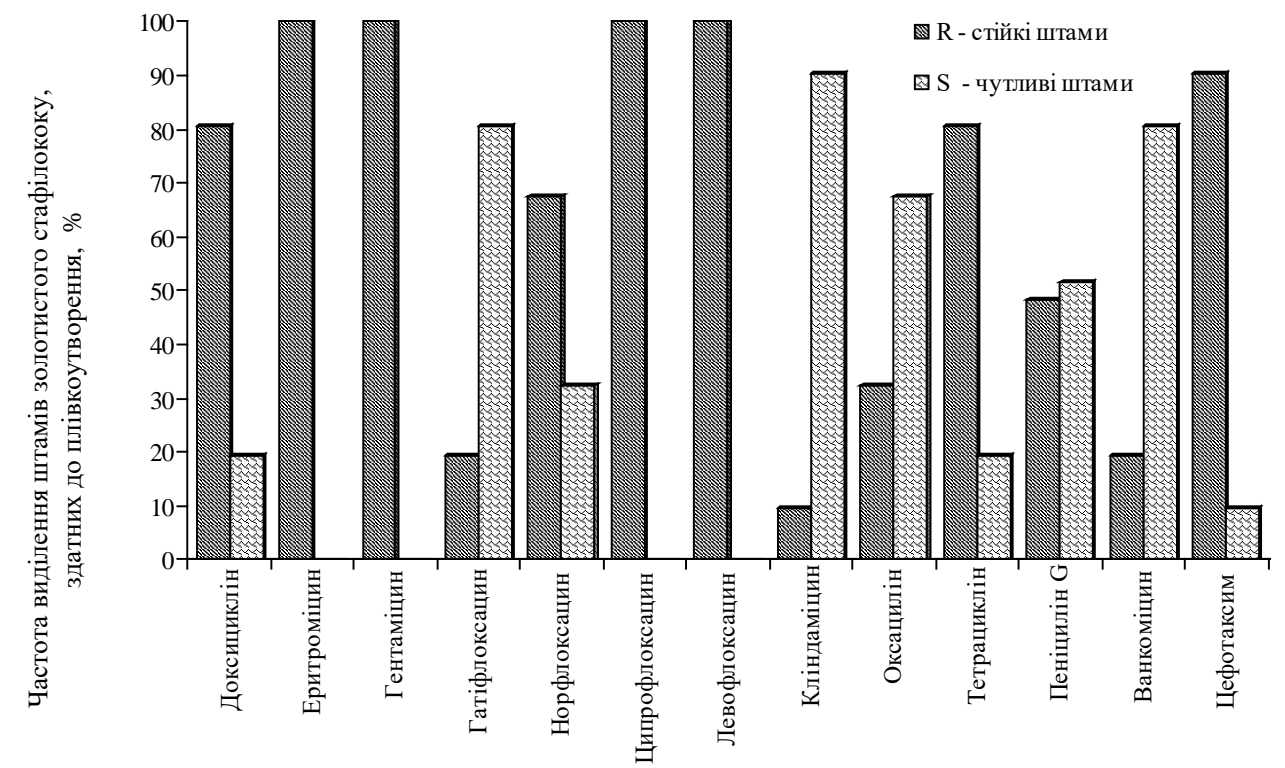

Рис. 2. Чутливість до антибіотиків штамів Staphylococcus aureus, здатних до плівкоутворення (n=31)

Високий відсоток стійких плівкотвірних штамів S. aureus відмічали до цефотаксиму (90,3\% культур) і препаратів тетрациклінового ряду - тетрацикліну та доксицикліну (80,6\% культур). Найчутливішими штами S. aureus, здатні до плівкоутворення, виявилися до кліндаміцину (90,3\%), ванкоміцину та гатифлоксацину (80,6\% культур). Штами золотистого стафілокока, не здатні до плівкоутворення, менш стійкі до антибіотиків, ніж плівкотвірні ізоляти (рис. 3). Лише цефотаксим пригнічував ріст 75,0\% штамів S. aureus. Усі дослідні культури виявилися чутливими до доксицикліну, гентаміцину, ципрофлоксацину, левофлоксацину та кліндаміцину. 75,0\% неплівкотвірних штамів золотистого стафілокока мали чутливість до ванкоміцину, оксациліну, гатифлоксацину та норфлоксацину. Що стосується антибіотикочутливості клінічних ізолятів P. aeruginosa, здат- 
них до плівкоутворення, то всі 24 штами проявили резистентність до ампіциліну, гентаміцину, іміпенему, цефотаксиму та цефтриаксону (рис. 4). Значна кількість штамів синьогнійної палички (75,0\%) мала стійкість до ципрофлоксацину. До інших антибіотичних препаратів відсоток стійких ізолятів не перевищував $50,0 \%$. Найчутливіші плівкотвірні штами $P$. aeruginosa до піперациліну та цефоперазон / сульбактаму. Ці антибіотики пригнічували ріст культур лише в 25,0\% випадків.

Штами синьогнійної палички, не здатні до плівкоутворення, характеризувались дещо меншою стійкістю до антибіотиків різних фармакологічних груп, ніж плівкотвірні ізоляти (рис. 5). Але спектр антибіотиків, до яких проявили резистентність неплівкотвірні штами, був майже тим самим. Усі виділені культури зберігали стійкість до гентаміцину, іміпенему та цефтриаксону. Ви- сокий відсоток (80,0\%) стійких штамів $P$. aeruginosa, не здатних до плівкоутворення, відмічали відносно цефоперазону, цефоперазон / сульбактаму, піперациліну та цефепіму. Найбільшу чутливість проявили неплівкотвірні штами $P$. aeruginosa до ципрофлоксацину (80,0\% ізолятів), а також до амікацину, ампіциліну, меропенему, норфлоксацину та цефотаксиму (60,0\% культур).

У зв'язку з тим, що високим ступенем резистентності характеризувалися переважно плівкотвірні ізоляти $P$. aeruginosa та $S$. aureus, на наступному етапі роботи досліджено їх антибіотикочутливість методом серійних розведень. Спектр антибіотиків (ципрофлоксацин, цефотаксим, гентаміцин) обрано за результатами попередньої серії дослідів. Саме до них виділені клінічні ізоляти збудників внутрішньолікарняних інфекцій проявляли максимальну стійкість.

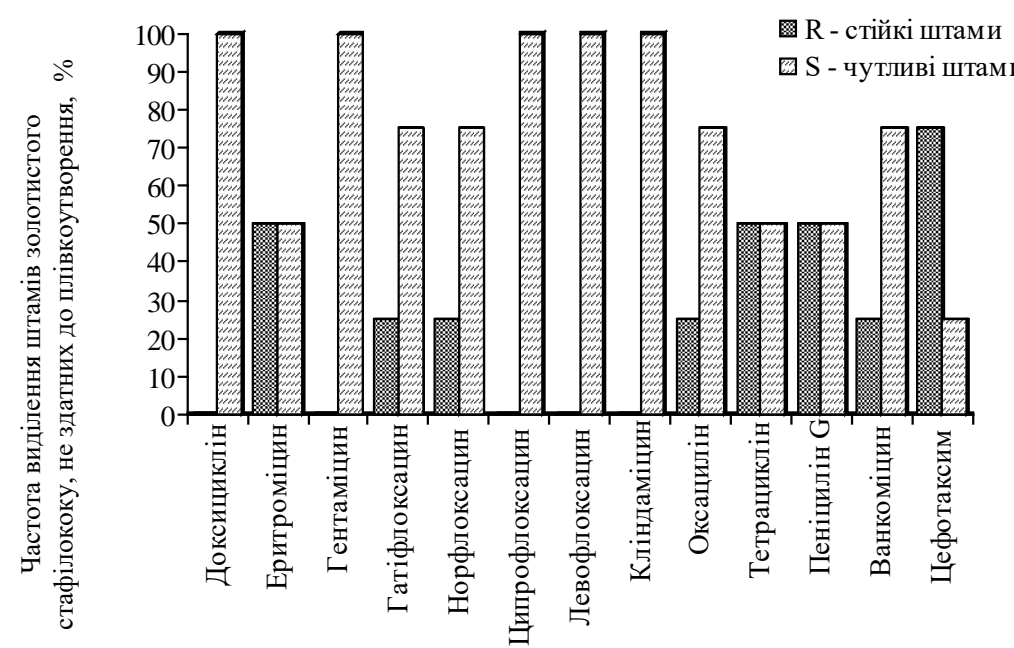

Pис. 3. Чутливість до антибіотиків штамів Staphylococcus aureus, не здатних до плівкоутворення (n=12)

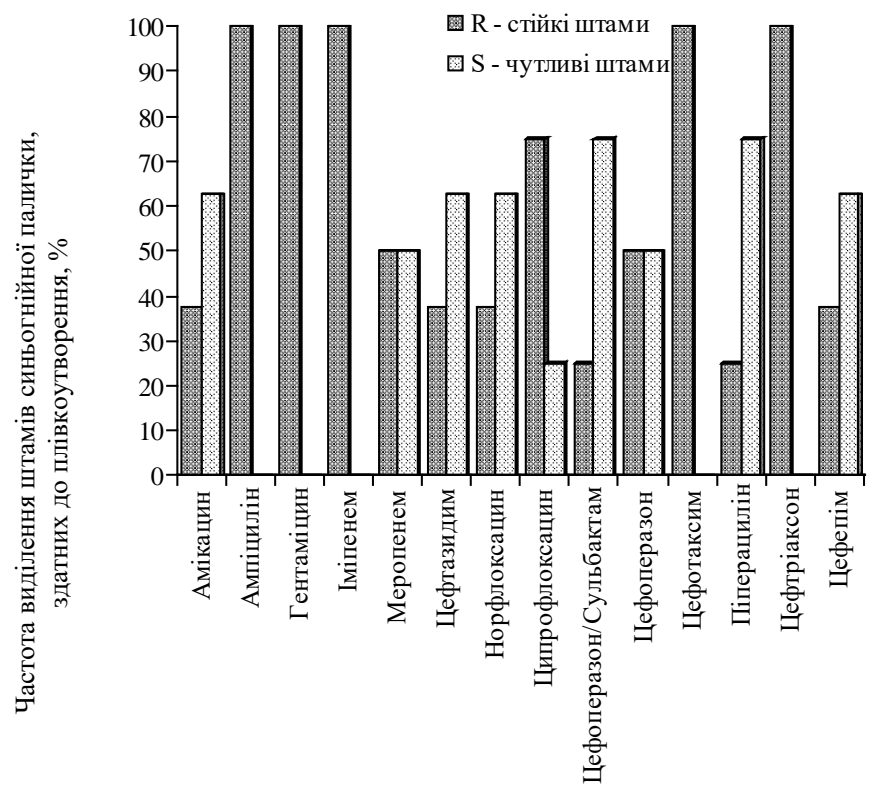

Рис. 4. Чутливість до антибіотиків штамів Pseudomonas aeruginosa, здатних до плівкоутворення ( $\mathrm{n}=24)$

Для п’яти плівкотвірних штамів $S$. aureus (№ 8, 9, 15, 23 і 29) значення мінімальної пригнічувальної концентрації (МПК) ципрофлоксацину збігалося 3 пороговим для цього антибіотика (4 мкт/мл), для двох культур (№ 1 і 19) - перевищувало порогове удвічі (8 мкг/мл), а ще для трьох (№ 6, 12, 22) - учетверо (16 мкг/мл). Значення мінімальної пригнічувальної концентрації цефотаксиму та гентаміцину для шести ізолятів золотистого стафілокока (№ 6, 8, 9, 15, 23 і 29) збігалися 3 пороговими та становили, відповідно, 64 і 16 мкг/мл. Для ізолятів S. aureus № 1 i 12 значення МПК цефотаксиму перевищувало порогове удвічі (128 мкг/мл), а для ізолятів № 19 і 22 - учетверо (256 мкг/мл).
Для штамів № 1 і 22 значення МПК гентаміцину перевищувало порогове удвічі (32 мкг/мл), а для ізолятів № 12 і 19 - учетверо (64 мкг/мл). Таким чином, методом серійних розведень установлено, що найрезистентнішими до трьох тестованих антибіотиків (ципрофлоксацину, цефотаксиму та гентаміцину) виявилися клінічні ізоляти S. aureus № 1, 6, 12, 19 і 22, які мали найвищі МПК дослідних антибактеріальних препаратів (табл. 1). Для трьох плівкотвірних штамів $P$. aeruginosa (№ 4, 19, 24) значення МПК ципрофлоксацину збігалося 3 пороговим для цього антибіотика (4 мкг/мл), для культур № 16 і 21 - перевищувало порогове, відповідно, удвічі та учетверо (8 і 16 мкг/мл), ще для трьох (№ 1, 11, 
18) - ушестеро (32 мкг/мл). Значення МПК цефотаксиму для чотирьох ізолятів синьогнійної палички (№ 4, 16, 19 і 24) збігалися 3 пороговими та становили 64 мкг/мл. Для ізолятів P. aeruginosa № 18 і 21 значення МПК цефотаксиму перевищувало порогове удвічі (128 мкг/мл), а для штамів № 1 i 11 - учетверо (256 мкг/мл). Для культур P. aeruginosa № 1 i 16 значення МПК гентаміцину перевищувало порогове удвічі (32 мкг/мл), для штамів № 11 і 18 - учетверо (64 мкг/мл), для штаму № 21 - увосьмеро. Таким чином, до трьох тестованих антибіотичних препаратів (ципрофлоксацину, цефотаксиму та гентаміцину) найрезистентнішими виявилися клінічні ізоляти синьогнійної палички № 1, 11, 18 і 21 (табл. 2).

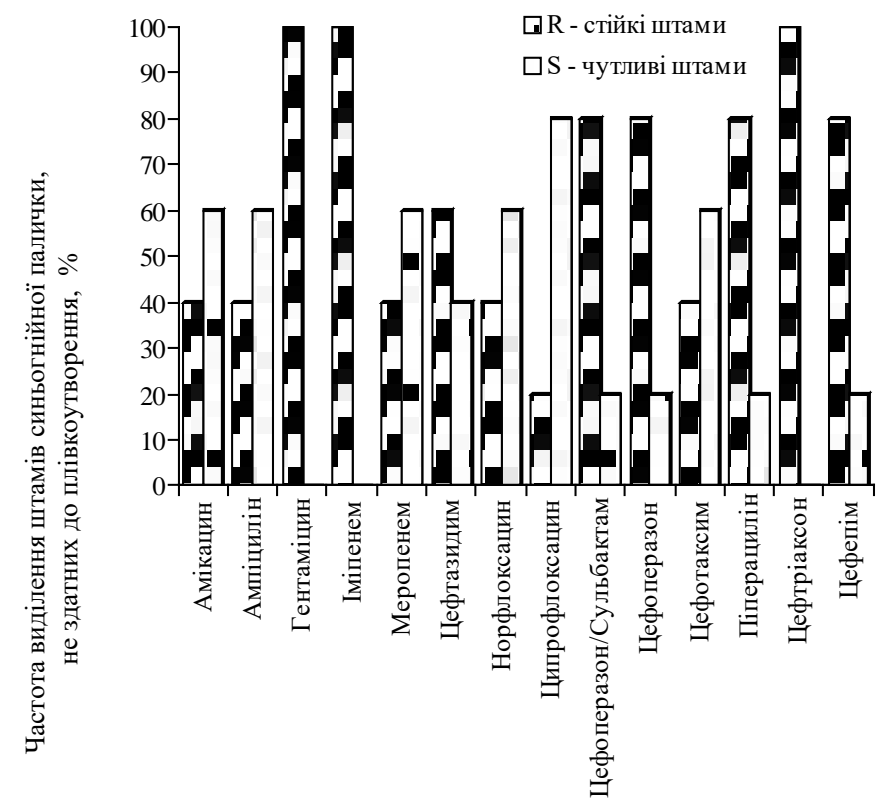

Рис. 5. Чутливість до антибіотиків штамів Pseudomonas aeruginosa, не здатних до плівкоутворення $(\mathrm{n}=15)$

Таблиця 1

Мінімальна пригнічувальна концентрація антибіотиків (мкг/мл) для штамів S. аureus, здатних до плівкоутворення $(\mathrm{n}=10)$

\begin{tabular}{|c|c|c|c|c|c|c|c|c|c|c|}
\hline \multirow{2}{*}{ Антибіотик } & \multicolumn{10}{|c|}{ Порядковий номер штаму S. aureus } \\
\hline & 1 & 6 & 8 & 9 & 12 & 15 & 19 & 22 & 23 & 29 \\
\hline Ципрофлоксацин & 8 & 16 & 4 & 4 & 16 & 4 & 8 & 16 & 4 & 4 \\
\hline Цефотаксим & 128 & 64 & 64 & 64 & 128 & 64 & 256 & 256 & 64 & 64 \\
\hline Гентаміцин & 32 & 16 & 16 & 16 & 64 & 16 & 64 & 32 & 16 & 16 \\
\hline
\end{tabular}

\section{Таблиця 2}

Мінімальна пригнічувальна концентрація антибіотиків (мкг/мл) для штамів P. aeruginosa, здатних до плівкоутворення (n = 8)

\begin{tabular}{|c|c|c|c|c|c|c|c|c|}
\hline \multirow{2}{*}{ Антибіотик } & \multicolumn{8}{|c|}{ Порядковий номер штаму P. aeruginosa } \\
\hline & 1 & 4 & 11 & 16 & 18 & 19 & 21 & 24 \\
\hline Ципрофлоксацин & 32 & 4 & 32 & 8 & 32 & 4 & 16 & 4 \\
\hline Цефотаксим & 256 & 64 & 256 & 64 & 128 & 64 & 128 & 64 \\
\hline Гентаміцин & 32 & 16 & 64 & 32 & 64 & 16 & 128 & 16 \\
\hline
\end{tabular}

Під час дослідження ефективності дії дезінфектантів отримано такі результати (табл. 3 і 4). Із двох видів хлорумісних дезінфектантів найефективнішим відносно всіх виділених культур золотистого стафілокока був «Дезактин». У $90,3 \%$ випадків $0,1 \%$ чи $0,2 \%$ розчин «Дезактину» пригнічував ріст виділених плівкотвірних ізолятів золотистого стафілокока. Що стосується неплівкотвірних ізолятів S. aureus, то до цього дезінфектанту чутливі всі 12 виділених збудників внутрішньолікарняних інфекцій. Менш ефективним дезінфектантом виявився «Неохлор табс». Кількість чутливих до нього штамів золотистого стафілокока, не здатних до плівкоутворення, не перевищувала 75,0\%, а у випадку плівкотвірних ізолятів - і того менше (61,3\%).

Під час дослідження ефективності дезінфектантів відносно псевдомонади встановлено, що у 100,0\% випадків ріст неплівкотвірних ізолятів пригнічував «Дезактин» $(0,1 \%$ або $0,2 \%$ розчин). Такий самий ефект спостерігали за дії $0,1 \%$ розчину «Неохлор табс». Плівкотвірні штами синьогнійної палички мали вищий ступінь резистентності до дії обох дезінфектантів: бактерицидний ефект $0,1 \%$ розчину «Неохлор табс» спостерігали в $75,0 \%$, а розчинів «Дезактин», -у 62,5\% випадків.

\section{Таблиця 3}

Чутливість виділених клінічних ізолятів S. aureus до дезінфектантів

\begin{tabular}{|c|c|c|c|c|c|}
\hline \multirow{2}{*}{ Об’єкт дослідження } & \multirow{2}{*}{$\begin{array}{c}\text { Вид і концентрація } \\
\text { дезінфектанту }\end{array}$} & \multicolumn{2}{|c|}{ Чутливі штами } & \multicolumn{2}{|c|}{ Стійкі штами } \\
\hline & & абсолютна кількість & $\%$ & абсолютна кількість & $\%$ \\
\hline \multirow{4}{*}{$\begin{array}{l}\text { Плівкотвірні штами } \\
\text { S. aureus, } \mathrm{n}=31\end{array}$} & «Дезактин», 0,1\% & 28 & 90,3 & 3 & 9,7 \\
\hline & «Дезактин», 0,2\% & 28 & 90,3 & 3 & 9,7 \\
\hline & «Неохлор табс», 0,03\% & 19 & 61,3 & 12 & 38,7 \\
\hline & «Неохлор табс», 0,1\% & 22 & 71,0 & 9 & 29,0 \\
\hline \multirow{4}{*}{$\begin{array}{l}\text { Неплівкотвірні штами } \\
\text { S. aureus, } \mathrm{n}=12\end{array}$} & «Дезактин», 0,1\% & 12 & 100,0 & 0 & 0,0 \\
\hline & «Дезактин», 0,2\% & 12 & 100,0 & 0 & 0,0 \\
\hline & «Неохлор табс», 0,03\% & 9 & 75,0 & 3 & 25,0 \\
\hline & «Неохлор табс», $0,1 \%$ & 9 & 75,0 & 3 & 25,0 \\
\hline
\end{tabular}


Таблиця 4

Чутливість виділених клінічних ізолятів P. aeruginosa до дезінфектантів

\begin{tabular}{|c|c|c|c|c|c|}
\hline \multirow{2}{*}{ Об’єкт дослідження } & \multirow{2}{*}{ Вид і концентрація дезінфектанту } & \multicolumn{2}{|c|}{ Чутливі штами } & \multicolumn{2}{|c|}{ Стійкі штами } \\
\hline & & абсолютна кількість & $\%$ & абсолютна кількість & $\%$ \\
\hline \multirow{4}{*}{$\begin{array}{l}\text { Плівкотвірні штами } \\
\text { P. aeruginosa, } \mathrm{n}=24\end{array}$} & «Дезактин», 0,1\% & 15 & 62,5 & 9 & 37,5 \\
\hline & «Дезактин», 0,2\% & 15 & 62,5 & 9 & 37,5 \\
\hline & «Неохлор табс», 0,03\% & 12 & 50,0 & 12 & 50,0 \\
\hline & «Неохлор табс», 0,1\% & 18 & 75,0 & 6 & 25,0 \\
\hline \multirow{4}{*}{$\begin{array}{l}\text { Неплівкотвірні штами } \\
\text { P. aeruginosa, } \mathrm{n}=15\end{array}$} & «Дезактин», 0,1\% & 15 & 100,0 & 0 & 0,0 \\
\hline & «Дезактин», 0,2\% & 15 & 100,0 & 0 & 0,0 \\
\hline & «Неохлор табс», 0,03\% & 12 & 80,0 & 3 & 20,0 \\
\hline & «Неохлор табс», 0,1\% & 15 & 100,0 & 0 & 0,0 \\
\hline
\end{tabular}

\section{Обговорення}

Моніторинг резистентності до антибактеріальних препаратів нозокоміальних штамів мікроорганізмів - обов'язкова складова системи інфекційного контролю багатьох країн світу (Murphy et al., 2016; Choi et al., 2016; Iliyasu et al., 2016; Ramirez-Blanco et al., 2017; Singh et al., 2017).

Під час визначення антибіотикочутливості виділених культур збудників внутрішньолікарніних інфекцій $P$. aeruginosa та $S$. aureus диско-дифузійним методом установлено, що найефективнішими антибіотичними препаратами проти клінічних ізолятів золотистого стафілокока виявилися кліндаміцин, ванкоміцин, оксацилін і гатифлоксацин, а синьогнійної палички - амікацин, меропенем і норфлоксацин. Найменш ефективним антибіотиком проти виділених штамів $S$. aureus можна вважати цефотаксим, а відносно синьогнійної палички - гентаміцин, іміпенем і цефтриаксон.

Отримані дані підтверджують результати досліджень, проведених Potochylova (2015) на базі Київської обласної клінічної лікарні. Вона показала, що із клінічного матеріалу від пацієнтів із гнійно-септичними ускладненнями найчастіше виділяли саме P. aeruginosa i S. aureus. Штами золотистого стафілокока характеризувались високою стійкістю до антибіотиків пеніцилінового та цефалоспоринового рядів, а синьогнійної палички - до імі- та меропенему, а також до цефалоспоринів: цефтазидиму, цефепіму, цефіксиму, цефазоліну, цефтибутену.

Negi et al. (2015) показали, що виділені з ран післяопераційних пацієнтів госпітальні штами $P$. aeruginosa виявилися найчутливішими до амікацину та піперациліну (54,5\% від загальної кількості ізолятів синьогнійної палички). До інших антибіотиків кількість чутливих ізолятів не перевищувала 27,3\%. Heydarpour et al. (2017) встановили, що високий рівень стійкості (понад 50,0\% культур) проявили нозокоміальні штами P. aeruginosa відносно цефтазидиму, цефтриаксону, ципрофлоксацину та гентаміцину. Амікацин пригнічував ріст виділених культур лише в $33,3 \%$ випадків, що суперечить нашим даним.

Стосовно антибіотикорезистентності клінічних ізолятів золотистого стафілокока отримані нами результати узгоджуються 3 наведеними іншими авторами (Kahsay et al., 2014; Manyahi et al., 2014; Belbas et al., 2017; Chen et al., 2017). Вони показали, що госпітальні штами $S$. aureus характеризувались найбільшою стійкістю до пеніцилінів (пеніциліну G, ампіциліну, амоксицилін / клавуланату) та цефалоспоринів (цефотаксиму, цефтриаксону), а найменшою - до кліндаміцину та ванкоміцину.

Виділені штами золотистого стафілокока, не здатні до плівкоутворення, характеризувалися вищим рівнем чутливості до тестованих антибіотичних препаратів, ніж плівкотвірні ізоляти. Відносно синьогнійної палички такої тенденції не відмічали. Усі виділені штами $P$. aeruginosa мали вищий ступінь резистентності до дії антибіотиків, ніж штами S. aureus. Найбільшу стійкість ізоляти золотистого стафілокока та синьогнійної палички, здатні до плівкоутворення, проявили до гентаміцину, цефотаксиму та ципрофлоксацину.

На наступному етапі роботи під час визначення антибіотикочутливості виділених збудників внутрішньолікарняних інфекцій, здатних до плівкоутворення, методом серійних розведень, показано, що МПК ципрофлоксацину та гентаміцину у двох ізолятів $P$. aeruginosa перевищували МПК цих антибіоти- ків у S. aureus, що свідчить про вищий рівень резистентності у клінічних штамів синьогнійної палички порівняно із золотистим стафілококом. Із 31 плівкотвірного ізолята S. aureus найвищі МПК за трьома тестованими антибіотиками мали п'ять штамів: № 1 і 19, а також № 6, 12 і 22; а із 24 дослідних культур P. aeruginosa - штами № 1, 11, 18, 21. Їх можна вважати ізолятами 3 множинною резистентністю. За сучасною мікробіологічною термінологією до штамів із множинною резистентністю (MDR) відносять ті, які мають резистентність щонайменше до трьох антибіотичних препаратів (Gill et al., 2011; Magiorakos et al., 2012).

За результатами визначення ефективності дії хлорумісних дезінфектантів «Дезактин» $\mathrm{i}$ «Неохлор табс» проти виділених збудників внутрішньолікарняних інфекцій встановлено, що штами S. aureus та $P$. aeruginosa, здатні до плівкоутворення, характеризувались вищим ступенем резистентності до дії обох видів дезінфектантів, ніж неплівкотвірні ізоляти. Отримані нами результати узгоджуються 3 даними Bridier et al. (2011) i Abdallah et al. (2014) про те, що плівкотвірні штами збудників нозокоміальних інфекцій стійкіші до дії дезінфектантів порівняно $з$ ізолятами, не здатними до утворення біоплівок. Причому найбільший бактерицидний ефект відносно плівкотвірних варіантів проявляють саме хлорумісні дезінфектанти (Bridier et al., 2011).

Отримані дані дозволяють констатувати, що у клінічних штамів S. aureus i $P$. aeruginosa - збудників внутрішньолікарняних інфекцій - існує прямий взаємозв'язок між показниками стійкості їх до антибіотиків та дезінфектантів і здатністю культур до плівкоутворення.

\section{Висновки}

Під час дослідження відокремлюваного ран пацієнтів у 79,6\% клінічних зразків виділено збудники внутрішньолікарняних інфекцій, ідентифіковані як S. aureus i $P$. aeruginosa. Здатність до плівкоутворення мали 31 із 43 (72,0\%) виділених штамів золотистого стафілокока і 24 із 39 (61,5\%) клінічних ізолятів синьогнійної палички. Всі плівкотвірні штами проявили стійкість до еритроміцину, гентаміцину, ципрофлоксацину та левофлоксацину. Найчутливішими вони виявилися до кліндаміцину $(90,3 \%)$, ванкоміцину $(80,6 \%)$ та гатифлоксацину $(80,6 \%$ культур). Неплівкотвірні штами золотистого стафілокока характеризувалися нижчим ступенем резистентності до антибіотиків, ніж плівкотвірні ізоляти. Лише цефотаксим пригнічував ріст 75,0\% штамів S. aureus. Усі дослідні культури виявилися чутливими до доксицикліну, гентаміцину, ципрофлоксацину, левофлоксацину та кліндаміцину.

Плівкотвірні клінічні ізоляти $P$. aeruginosa проявили резистентність до ампіциліну, гентаміцину, іміпенему, цефотаксиму та цефтриаксону. Найчутливіші (75,0\% культур) вони до піперациліну та цефоперазон / сульбактаму. Неплівкотвірні штами синьогнійної палички зберігали стійкість відносно гентаміцину, іміпенему та цефтриаксону. Найбільшу чутливість проявили вони до ципрофлоксацину (80,0\% ізолятів), а також до амікацину, ампіциліну, меропенему, норфлоксацину та цефотаксиму $(60,0 \%$ культур). Вищий рівень резистентності мали клінічні штами синьогнійної палички порівняно із золотистим стафілококом за значеннями МПК ципрофлоксацину та гентаміцину. 
Найефективнішим дезінфектантом проти виділених клінічних неплівкотвірних штамів золотистого стафілокока та синьогнійної палички виявився «Дезактин» у концентрації $0,1 \%$ або $0,2 \%$. Відносно ізолятів $S$. aureus, здатних до плівкоутворення, його ефективність знизилась на 9,7\%. Найкращий бактерицидний ефект проти плівкотвірних штамів $P$. aeruginosa проявив $0,1 \%$ розчин «Неохлор табс». Він пригнічував ріст $75,0 \%$ тестованих культур.

У клінічних штамів S. aureus i P. aeruginosa - збудників внутрішньолікарняних інфекцій - існує прямий взаємозв'язок між показниками стійкості їх до антибіотиків та дезінфектантів і здатністю культур до плівкоутворення.

\section{References}

Abdallah, M., Benoliel, C., Drider, D., Dhulster, P., \& Chihib, N. E. (2014). Biofilm formation and persistence on abiotic surfaces in the context of food and medical environments. Archives of Microbiology, 196, 453-472.

Ali, Z., Mumtaz, N., Naz, S. A., Jabeen, N., \& Shafique, M. (2015). Multi-drug resistant Pseudomonas aeruginosa: A threat of nosocomial infections in tertiary care hospitals. The Journal of the Pakistan Medical Association, 1, 12-16.

Ansari, S., Nepal, H. P., Gautam, R., Rayamajhi, N., Shrestha, S., Upadhyay, G., Acharya, A., \& Chapagain, M. L. (2014). Threat of drug resistant Staphylococcus aureus to health in Nepal. BMC Infectious Diseases, 14, 1-5.

Baldan, R., Cigana, C., Testa, F., Bianconi, I., De Simone, M., Pellin, D., Di Serio, C., \& Bragonzi, A. (2014). Adaptation of Pseudomonas aeruginosa in cystic fibrosis airways influences virulence of Staphylococcus aureus in vitro and murine models of co-infection. PLoS One, 9(3), e89614.

Belbase, A., Pant, N. D., Nepal, K., Neupane, B., Baidhya, R., Baidya, R., \& Lekhak, B. (2017). Antibiotic resistance and biofim production among the strains of Staphylococcus aureus isolated from pus/wound swab samples in a tertiary care hospital in Nepal. Annals of Clinical Microbiology and Antimicrobials, 16,15

Bridier, A., Dubois-Brissonnet, F., Greub, G., Thomas, V., \& Briandet, R. (2011). Dynamics of the action of biocides in Pseudomonas aeruginosa biofims. Antimicrobial Agents and Chemotherapy, 55, 2648-2654.

Chadha, T. (2014). Bacterial biofilms: Survival mechanisms and antibiotic resistance. Journal of Bacteriology and Parasitology, 5(3).

Chen, K., Huang, Y., Song, Q., Wu, C., Chen, X., \& Zeng, L. (2017). Drug-resistance dynamics of Staphylococcus aureus between 2008 and 2014 at a tertiary teaching hospital, Jiangxi Province, China. BMC Infectious Diseases, 17, 97.

Choi, J. Y., Kwak, Y. G., Yoo, H., Lee, S. O., Kim, H. B., Han, S. H., Choi, H. J., Kim, H. Y., Kim, S. R., Kim, T. H., Lee, H., Chun, H. K, Kim, J. S., Eun, B. W., Kim, D. W., Koo, H. S., Cho, E. H., \& Lee, K. (2016). Korean Nosocomial Infections Surveillance System. Trends in the distribution and antimicrobial susceptibility of causative pathogens of device-associated infection in Korean intensive care. Journal of Hospital Infections, 92(4), 363-371.

Dasgupta, S., Das, S., Chawan, N. S., \& Hazra, A. (2015). Nosocomial infections in the intensive care unit: Incidence, risk factors, outcome and associated pathogens in a public tertiary teaching hospital of Eastern India. Indian Journal of Critical Care Medicine, 19(1), 14-20.

Gill, M. M., Usman, J., Kaleem, F., Hassan, A., Khalid, A., Anjum, R., \& Fahim, Q. (2011). Frequency and antibiogram of multi-drug resistant Pseudomonas aeruginosa. Journal of the College of Physicians and Surgeons Pakistan, 21(9), 531-534.

Heydarpour, F., Rahmani, Y., Heydarpour, B., \& Asadmobini, A. (2017). Nosocomial infections and antibiotic resistance pattern in open-heart surgery patients at Imam Ali Hospital in Kermanshah, Iran. GMS Hygiene and Infection Control, 12, 1-8.

Iliyasu, G., Daiyab, F. M., Tiamiyu, A. B., Abubakar, S., Zaiya, G. H., Sarki, A. M., \& Habib, A. G. (2016). Nosocomial infections and resistance pattern of common bacterial isolates in an intensive care unit of a tertiary hospital in Nigeria: A 4-year review. Journal of Critical Care, 34, 116-120.

Kahsay, A., Mihret, A., Abebe, T., \& Andualem, T. (2014). Isolation and antimicrobial susceptibility pattern of Staphylococcus aureus in patients with surgical site infection at Debre Markos Referral Hospital, Amhara Region, Ethiopia. Archives of Public Health, 72, 16.
Khan, H. A., Ahmad, A., \& Mehboob, R. (2015). Nosocomial infections and their control strategies. Asian Pacific Journal of Tropical Biomedicine, 5(7), 509-514.

Kim, S., Lieberman, T. D., \& Kishony, R. (2014). Alternating antibiotic treatments constrain evolutionary paths to multidrug resistance. Proceedings of the National Academy of Sciences of the United States of America, 111(40), 14494-14499.

Magiorakos, A.-P., Srinivasan, A., Carey, R. B., Carmeli, Y., Falagas, M. E., Giske, C. G., Harbarth, S., Hindler, J. F., Kahlmeter, G., Olsson-Liljequist, B., Paterson, D. L., Rice, L. B., Stelling, J., Struelens, M. J., Vatopoulos, A., Weber, J. T., \& Monnet, D. L. (2012). Multidrug-resistant, extensively drugresistant and pandrug-resistant bacteria: An international expert proposal for interim standard definitions for acquired resistance. Clinical Microbiology and Infection, 18(3), 268-281.

Manyahi, J., Matee, M. I., Majigo, M., Moyo, S., Mshana, S. E., \& Lyamuya, E. F. (2014). Predominance of multi-drug resistant bacterial pathogens causing surgical site infections in Muhimbili National Hospital, Tanzania. BMC Research Notes, 7, 500.

Menegueti, M. G., Canini, S. R. M. da S., Bellissimo-Rodrigues, F., \& Laus, A. M. (2015). Evaluation of nosocomial infection control programs in health services. Revista Latino-Americana de Enfermagem, 1, 98-105.

Murphy, R. A., Okoli, O., Essien, I., \& Teicher, C. (2016). Multidrug-resistant surgical site infections in a humanitarian surgery project. Epidemiology Adn Infection, 144(16), 3520-3526.

Nathwani, D., Raman, G., Sulham, K., Gavaghan, M., \& Menon, V. (2014). Clinical and economic consequences of hospital-acquired resistant and multidrug-resistant Pseudomonas aeruginosa infections: A systematic review and meta-analysis. Antimicrobial Resistance and Infection Control, 3, 32.

Negi, V., Pal, S., Juval, D., Sharma, M. K., \& Sharma, N. (2015). Bacteriological profie of surgical site infections and their antibiogram: A study from resource constrained rural setting of Uttarakhand State. India Journal of Clinical and Diagnostic Research, 9(10), 17-20.

O’Toole, G. F., Kaplan, H. B., \& Kolter, R. (2000). Biofilm formation as microbial development. Annual Review of Microbiology, 54, 49-79.

Ramirez-Blanco, C. E, Ramirez-Rivero, C. E. Diaz-Martinez, L. A. \& SosaAvila, L. M. (2017). Infection in burn patients in a referral center in Colombia. Burns, in press.

Rezai, M. S., Bagheri-Nesami, M., \& Nikkhah, A. (2017). Catheter-related urinary nosocomial infections in intensive care units: An epidemiologic study in North of Iran. Caspian Journal of Internal Medicine, 8(2), 76-82.

Scherbaum, M., Kösters, K., Mürbeth, R. E., Ngoa, U. A., Kremsner, P. G., Lell, B., \& Alabi, A. (2014). Incidence, pathogens and resistance patterns of nosocomial infections at a rural hospital in Gabon. BMC Infectious Diseases, 14, 124.

Singh, S., Malhotra, R., Grover, P., Bansal, R., Kaur, R., \& Jindal, N. (2017). Antimicrobial resistance profile of methicillin-resistant Staphylococcus aureus colonizing the anterior nares of health-care workers and outpatients attending the remotely located tertiary care hospital of North India, 9(4), 317-321.

Singh, S., Singh, S. K., Chowdhury, I., \& Singh, R. (2017). Understanding the mechanism of bacterial biofilms resistance to antimicrobial agents. The Open Microbiology Journal, 11, 53-62.

Sonmezer, M. C., Ertem, G., Erdincm, F. S., Kilic, E. K., Tulek, N., Adiloglu, A., \& Hatipoglu, C. (2016). Evaluation of risk factors for antibiotic resistance in patients with nosocomial infections caused by Pseudomonas aeruginosa. Canadian Joumal of Infectious Diseases and Medical Microbiology, 2.

Sowash, M. G., \& Uhlemann, A. C. (2014). Community-associated methicillinresistant Staphylococcus aureus case studies. Methods of Molecular Biology, 1085, 25-69.

Tong, S. Y., Davis, J. S., Eichenberger, E., Holland, T. L., \& Fowler, V. G. J. (2015). Staphylococcus aureus infections: Epidemiology, pathophysiology, clinical manifestations, and management. Clinical Microbiology Reviews, 28(3), 603-661.

Vuong, C., Yeh, A., Cheung, G., \& Otto, M. (2016). Investigational drugs to treat methicillin-resistant Staphylococcus aureus. Expert Opinion on Investigational Drugs, 25(1), 73-93.

Wang, L., \& Ruan, S. (2017). Modeling nosocomial infections of methicillinresistant Staphylococcus aureus with environment contamination. Scientific Reports, 7, 1-12. 